\title{
Improvement in road accessibility vs. the polycentricity of the Mazovian settlement network
}

\section{Tomasz Komornicki}

\begin{abstract}
The purpose of the article is to assess the degree to which the implemented road construction projects contributed to the strengthening of the polycentric pattern of the Polish region of Mazovia (Mazowieckie voivodeship). The investigations conducted may also enable a broader consideration of the effectiveness of transport policy in the context of the most important spatial policy and territorial cohesion objectives of the EU. The spatial scope of the research encompasses the region of Mazovia, but the analyses performed also referto the entire country. The analysis carried out had a dynamical character and concerns the period between 2007 and 2017. It indicates that in 2007-2017 there has been an improvement in accessibility, both from the national and regional perspective. The reason for this improvement lay mainly in the large national-level transport-related projects and, to a lesser degree, in some of the modernizations of the regional routes. The spatial differentiation of accessibility changed its character. It no longer resulted directly from the geographical distribution of towns and their historical division, associated with the course of Vistula river. It became a derivative of the state of advancement of the project implementation process. The projects executed allowed for the strengthening of some of the regional (Radom) and subregional centres (Siedlce, Ostrołęka), providing the capacity for increasing the degree of polycentricity. The actual effect of these undertakings should, however, be assessed in the demographic context. There are also some parts of the region where the improvement of accessibility has not occurred (especially in the northern part of the region, including the town of Ciechanów), or has occurred solely within the national perspective (interactions with other bigger towns of Poland, as in the case of the north-western fringe of the region, including the town of Płock). It can therefore be concluded that the road construction projects had a positive influence on the polycentricity of the region. So far, though, this effect has been spatially selective. It ought to be treated rather as the creation of an opportunity for developing a more equilibrated settlement pattern. Whether this opportunity will be taken advantage of depends upon the demographic situation and the stimulation of other endogenous development potentials in the regional and subregional urban centres.
\end{abstract}

Key words: accessibility, Mazovia, polycentricity, roads

\section{Introduction}

Polycentricity is the notion which lies at the foundations of the European Union documents referring to space [ESDP 1999; Territorial Agenda 2007 and 2011]. The concept took shape in the course of the search for a counterweight to the domination of the core of the European Union and the cities located within it [Kunzman, Wegener 1991]. Most frequently, polycentricity is understood as strengthening the various types of cities/towns and their urban regions, the functioning of urban networks and functional relations within functional areas [Zaucha, Szlachta 2017]. Polycentricity amounts to a new paradigm of assessment of the settlement network, contrasted with the traditional perception of this network in the context of core-periphery [Copus 2001]. One of the six priorities defined in the EU Territorial 
Agenda 2020 is supporting polycentric and sustainable territorial development. Such development is perceived as one of the elements of territorial cohesion [Meijers et al. 2007] and hence as the basis for the cohesion policy, as implemented by the European Union.

In the currently valid Polish National spatial development concept 2030 the first objective of the policy of spatial development is to improve the competitiveness of major Polish urban centres in the European context through functional integration while preserving the pro-cohesive polycentric settlement structure. At the same time, the third of the objectives indicated is the improvement of Poland's connectivity in various dimensions by developing transport and telecommunication infrastructure. Additionally, in the middle of 2011, in the framework of the Polish EU Presidency, a background document was prepared, the main purpose of which was to integrate the pan-European development objectives included in the Europe 2020 document and the priorities of the previously mentioned EU Territorial Agenda 2020 [Bohme et al. 2011; Zaucha et al. 2014]. The document proposed a set of five policy domains, referred to as territorial keys, which could play the role of development territorialisation indicators. The identification and choice of these keys resulted from an in-depth analysis concerning the "linking issues" pertaining to both documents mentioned [Zaucha et al. 2014]. One of the keys chosen was spatial accessibility.

According to the definitions adopted in the ESPON 1.1.1 project [ESPON 1.1.1. Final Report 2004], the determinants of polycentricity are constituted by three criteria: size (lack of magnitude-related domination of one or a couple of centres), location (even distribution of the biggest cities in geographical space) and connectivity (existence of functional linkages in the majority of relations between the biggest cities, and not only in the direction of one or a few of them). A convenient measure of the last criterion may be spatial accessibility, understood as the possibility of fast transfer of people and goods between the nodes of the settlement system. When assessing the fulfillment of all the criteria, though, the size of the units analysed must be taken into consideration. In the case of the European scale (as in the original ESPON study), countries like France or Hungary are in an obvious manner less polycentric than Germany or Poland. The situation is more ambiguous at the regional level. Most frequently - the smaller the territorial units analysed, the more they are, in a natural manner, monocentric. A typical monocentric region (in the sense of all the criteria mentioned) is constituted by the Mazovia region. This is due to the large demographic and economic potential of Warsaw and its metropolitan area. Yet, it is possible to strengthen the polycentric setting also in the framework of such a region, in particular by extending support for the linkages between towns, which might ultimately equilibrate the functional setting.

From among the three criteria of polycentricity, it is the criterion of connectivity that is most susceptible to the supporting activities (understood broadly as including support for both functional linkages and infrastructure). At the same time, the criteria of size and location change slowly. In the countries which feature high growth rates, such as Poland, one encounters primarily concentration processes, this being the consequence of the systemic transformation and the polarization of living conditions. The "victims" of these processes are 
frequently the middle-sized towns [Śleszyński et al. 2017]. The cohesion policy, along with other undertakings of territorial dimension (including the previously mentioned support for the connectivity criterion), is aimed at stopping these negative tendencies.

In the studies devoted to the infrastructural foundations of the polycentric development of Mazovia (carried out in the framework of the project entitled Development Trends of Mazovia) a scenario-based image of the region's development was proposed [Komornicki et al. 2012; Bański, Czapiewski 2015]. The basis for this proposal was the network of the subregional towns which formerly, during the last quarter of the $20^{\text {th }}$ century, were regional seats. These were: Płock, Radom, Siedlce, Ostrołęka and Ciechanów. In the first, "basic" scenario, considered to be the most realistic one, it was assumed that the only centres, which will in fact spatially equilibrate the domination of Warsaw, would be Radom and Płock. In the eastern and northern parts of the region this role would have to be played by the network of county centres, without indication of the settlement dominants. In the second, "positive", scenario, the position of all five subregional centres is strengthened, and the directions of linkages undergo diversification. The symmetry of functional connections is enhanced, and hence also strengthened is the diffusion of the development factors from Warsaw to the five towns, as well as the linkages between these towns with omission of the capital city. The third, "negative", scenario assumed the failure of the effective equilibration of development and a relative decrease in the role of not only the towns situated in the eastern and northern parts of the region, but also of Radom and Płock. At the same time, the directions of interconnections would in the last case remain oriented solely at Warsaw [Bański, Czapiewski 2015]. It can be admitted that this third scenario would therefore signify further washing out by Warsaw of resources from the entire region, including the biggest of the middle-sized towns. The report proposes a number of spatial solutions meant to support the "positive" variant or the "basic" one and to counteract the further strengthening of the capital as the core of the typical monocentric region (the "negative" variant). Many of the proposed undertakings are associated with the development of transport infrastructure and improvement of spatial accessibility.

The prerequisites, formulated in the Development Trends of Mazovia, were afterwards turned into a new version of the spatial development plan of the region in 2014, wherein the polycentric setting of the settlement network was assumed to be an element of the region's desired ultimate spatial structure. Simultaneously, the same document indicates as one of the seven development objectives the improvement of accessibility of Warsaw, the regional and subregional centres, and the county towns, which play a major role in the multifunctional development potential of the region. Two towns, Płock and Radom, were assumed to be the regional centres, while the remaining three - to be the subregional centres. The plan thus refers to the two previously commented development scenarios, the "basic" and the "positive" one.

At the same time, in the subsequent years, transport investment projects were being continued, funded largely, although not uniquely, with funds from the European Union, distributed both at the central/national level (through the Infrastructure and Environment 
Operational Programme) and the regional one (the Regional Operational Programme of the Mazovia Region). Transport-wise, accessibility was improving, especially the road accessibility of the region. Among the most important implemented road projects were: segments of the A2 motorway (from Warsaw towards Lodz and the bypass of Mińsk Mazowiecki) and of the expressways S7 (between Grójec and Radom) and S8 (from Radziejowice to the border of the region and from Radzymin to Wyszków). A significant part of the Warsaw ring road was also constructed. An essential supplement was provided by new projects and modernizations concerning regional roads. Among the biggest was the new bridge across the Vistula in Kamien (providing a connection with the region of Lublin).

The purpose of this article is to assess to what degree the implemented road projects contributed to the strengthening of the polycentric pattern of the Mazovia region, and which of the previously considered scenarios of spatial development is made more likely by the realized undertakings. The conducted study may also enable a broader reflection on the effectiveness of the transport policy in the context of the most important EU objectives concerning spatial policy and territorial cohesion.

The spatial scope of the study includes the region of Mazovia, but the analyses carried out refer to the entire country, since the applied methodology (see further on) includes, in particular, the indicator of potential accessibility, calculated at the national level. In the tables of results the values of the indicators are distinguished for the capital city and for five Mazovian subregional centres. The analysis performed has a dynamical character and covers the period 2007-2017, which may, to a high extent, be identified with the previous European Union programming period (2007-2013 plus the period for project completion). Yet, the study in fact took into account all the projects executed in the years mentioned, also those carried out without the contribution of European funds (e.g. the segment of the A2 motorway between Stryków and Konotopa), as well as the first effects of the subsequent programming period (2014-2020). The most recent empirical data was used, concerning the state of the road network. The choice of analyzing only road accessibility (without taking into account other means of transport) was deliberate. During the analyzed period the scale of road investments in the region of Mazovia was the biggest. Besides, their effects can be directly expressed through the actual accessibility for inhabitants and businesses. In the case of other transport branches this often depends upon the internal policies of the carriers (especially in the case of rail transport).

\section{Methods applied}

Accessibility constitutes a good evaluation metric. In analyses of polycentricity it can be identified with the approximation of its third criterion - connectivity. Accessibility can be measured with infrastructural equipment, distance, as well as cumulative, personified, or potential indicators [Geurs, Ritsema van Eck 2001; Geurs, van Wee 2004; Komornicki et al. 2010; Rosik 2012; Komornicki, Stępniak 2015]. The present study made use of two interconnected methods of analyzing accessibility: potential and time accessibility (isochrones). 
Studies of accessibility - in the context of new transport projects and investments have been carried out for many years now, mainly by German researchers [Spiekermann, Schurmann 2007], and also for the purposes of the ESPON project studies [1.2.1., TRACC, SeGI, FOCI, Spekermann at al. 2013]. Apart from that, some countries, e.g. Spain, Poland and Czechia, conduct this kind of analyses for their territories. In Poland, in 2015-2017 work has been carried out on the modernization and updating of the Indicator of Interbranch Transport Accessibility (Polish acronym: WMDT II), used by the Polish Ministry of Investment and Development. This work was carried out by the Institute of Geography and Spatial Organization of the Polish Academy of Sciences. Its effect is the possibility to constantly monitor the changes in accessibility in both multimodal and modal perspectives [Rosik et al. 2015]. The indicators associated with accessibility became the "result indicators" for numerous EU (2014-2020) operational programmes within the territory of Poland.

Potential accessibility is based on the negative exponential distance-decay function, which produces the well-known potential accessibility indicator. The closer the opportunity (destination), the more it contributes to accessibility. The larger the opportunity (mass of each region considered, e.g. population), the more strongly it influences the accessibility. The travel time between any pair of transport zones was calculated by applying the method of identifying the shortest travel routes according to Dijkstra's algorithm [Hansen 1959; Geurs, van Eck 2001].

The basic feature of potential accessibility is the fact that the attractiveness of destinations increases along with their size and decreases with the increase of physical, temporal and economic distance:

$$
A_{i}=\sum_{j} f_{1}\left(M_{j}\right) f_{2}\left(c_{i j}\right)
$$

$A_{i}$ - transport accessibility of a unit (transport district) i,

$M_{j}$ - mass available in unit (transport district) $\mathrm{j}$,

$c_{i j}$ - total temporal distance linked with travel/transportation services from transport district i to transport district j [Rosik et al. 2015].

The methodology and the values of the accessibility indicators used in the present article, are identical with those used in calculations of the WMDT II indicator [Komornicki et al. 2018]. They are based on the traffic model elaborated at the Institute of Geography and Spatial Organization of the Polish Academy of Sciences [Komornicki et al. 2010].

Potential accessibility can be calculated for various sets of units. This implies consideration of only those travel destinations which are contained in the sets accounted for. In the study here reported road accessibility was assessed in two ways;

- with respect to all the travel destinations (municipalities) on the territory of Poland the "national level" indicator,

- with respect only to the travel destinations (municipalities) within the region of Mazovia - the "regional level" indicator. 
The first perspective can be treated as an approximation of the position of the towns and municipalities of the region within the entire national polycentric settlement system. This position may depend upon the (connectivity) relations with units located in other regions. The second perspective assumes the perception of the Mazovia region as an island, isolated from the outer world. It provides the image of the connectivity criterion values as the internal measure of the region's polycentricity. The correct assessment of the effects of road investment projects requires using both of these perspectives.

Additionally, the study used a simple method of measuring temporal accessibility between the main regional and subregional centres. This approach also provides an image of the internal polycentricity of the region and of the dynamics in this respect. It provides an image of the network pattern of the biggest centres, which is not disturbed by the extraregional and local relations. In the calculation of travel times, the same traffic speed model was used as previously mentioned [Komornicki et al. 2010], which ensured complete compatibility with the method of potential accessibility.

\section{Changes of accessibility in Mazovia in the "national level" perspective}

Both in 2007 and in 2017 the potential road accessibility in the region of Mazovia (related to the national average) had a very uneven distribution (Figs 1a, 1b). It was highest in the surroundings of Warsaw and in the zone to the south-west of the capital city, and decidedly the lowest in the northern and eastern fringes of the region. As we compare the two spatial distributions, we see a significant improvement which took place in many parts of the analysed area. It is characteristic in this context that in 2017 the maps show much more distinctly the main transport routes (primarily motorways and expressways). In the year 2007 the differences in the speed with which one could move over the individual routes were not really significant (the exceptions were the dual carriageway road towards Katowice and the fragment of the S7 expressway in the vicinity of Nowy Dwór Mazowiecki). Consequently, the values of the accessibility indicator depended primarily upon the geographical location with respect to the biggest masses (population concentrations) in Poland. This entailed a concentric pattern of accessibility levels around the capital city and higher values towards the southwest of Warsaw (closeness of Lodz and of other large national centres), with lower values in the east and north (lack of bigger towns and generally lower population density). The construction of new roads (motorways and expressways) modified this spatial distribution. The A2 motorway strengthened the position of the Warsaw-Lodz axis. Furthermore, belts of distinctly better accessibility appeared along the S7 road to the south of Warsaw towards Radom and along the S8 road to the north-east, in the direction of Wyszków and - farther away - Białystok. The spatial reach of the zones with the lowest levels of accessibility got clearly smaller, first of all in the south of the region, but then also in the northern and eastern parts. From among the five towns considered as the centres of equilibrating the polycentric development of Mazovia, Radom moved into the zone of better accessibility. The pattern of accessibility in 2017 was slightly more symmetric with respect to the axis of the Vistula river. 
This means that despite the general increase in the differentiation of the levels of accessibility, the historical division into western and eastern Poland was being gradually overcome in the region.

Figure 2 presents the relative (in percentage terms) change in the levels of road accessibility, which took place in the years 2007-2017 due to the realization of new projects, and partly due to shifts in population distribution (migration to the metropolitan area of Warsaw and the suburbanization processes taking place therein). The areas featuring the biggest changes in the levels of the indicator are concentrated along the already mentioned routes: A2, S7 and S8, but also in the vicinity of other completed fragments of roads. Some of the peripheral areas of the region witnessed an improvement in the national level accessibility owing to projects realized outside the region (e.g. in the Świętokrzyskie and WarmińskoMazurskie regions, along the S7 expressway). The area situated to the south of Płock profited from the north-south A1 motorway passing nearby. Warsaw itself experienced a relatively smaller improvement in its accessibility. On the other hand, the suburban municipalities neighbouring Warsaw, especially in the western and northern parts of the agglomeration, noted a clear improvement. This results partly from the course of the already completed fragments of the Warsaw expressway ring. At the same time, improvement was the least distinct in the zones situated to the north-west and south-east of the capital city. From among the five analysed centres of development equilibration, it was Radom that found itself in the zone of faster improvement in accessibility, with Płock, Siedlce and Ostrołęka following. Ciechanów lagged very distinctly behind. There are places where the Vistula still constitutes the borderline, indicating a substantial difference in the effects of infrastructure development (e.g. along the segment between Nowy Dwór and Płock, but also immediately to the south of Warsaw). In the northern part of the region a similar barrier to the advantages from the new road projects appears to be constituted by the Narew river. In both cases this might indicate an insufficient number of bridges across the bigger rivers.

An example of the effectiveness of this type of investment project may be provided by the south-eastern fringe of the region, where a new bridge was constructed across the Vistula in Kamień. A significant improvement in the accessibility of the municipalities in the county of Lipsko is partly due to the shortening of travel time to the important centre of Lublin, the capital of the neighbouring region.

When analyzing the state and dynamics of road accessibility from the "national level" perspective, we must admit that the territorial polarisation of Mazovian local units' transport position increased in the 2007-2017 period. This was unavoidable in the context of accelerated development of the road network. As demonstrated by the nationally-oriented studies [Komornicki et al. 2018], after a certain level of saturation with transport infrastructure is attained, the territorial differences ought to start to decrease again. This supposition is treated as a significant premise for not stopping the investment projects in road transport. As of now, though, it should be stated that the national investments into roads were advantageous for the western, north-eastern and southern parts of the region, while relatively worsening (in relation to other areas) the situation in the northern and eastern parts. 


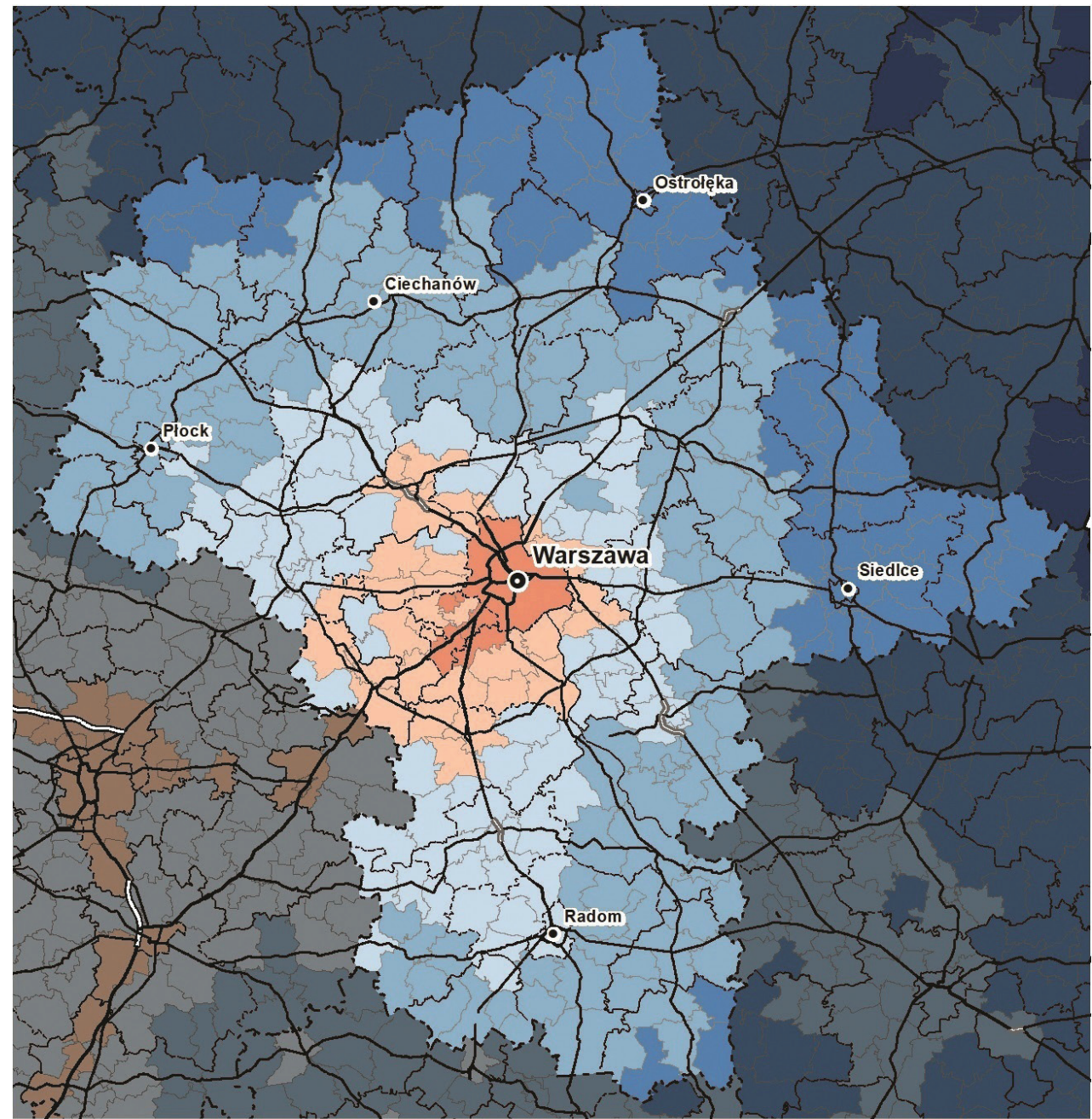

Potential accessibility (2007)

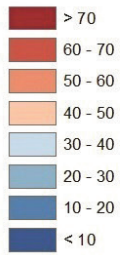

Road category

Motorway

- Expressway, single carriageway

Expressway, dual carriageway

- National, dual carriageway

- National
Borders

- - region

-.-- county

municipality

$0 \quad 15 \quad 30$ $60 \mathrm{~km}$

Fig. 1a. Potential road accessibility of the Mazovia region from the "national level" perspective in 2007

Source: database of the Institute of Geography and Spatial Organization,

Polish Academy of Sciences (IGSO PAS); elaboration: S. Goliszek 


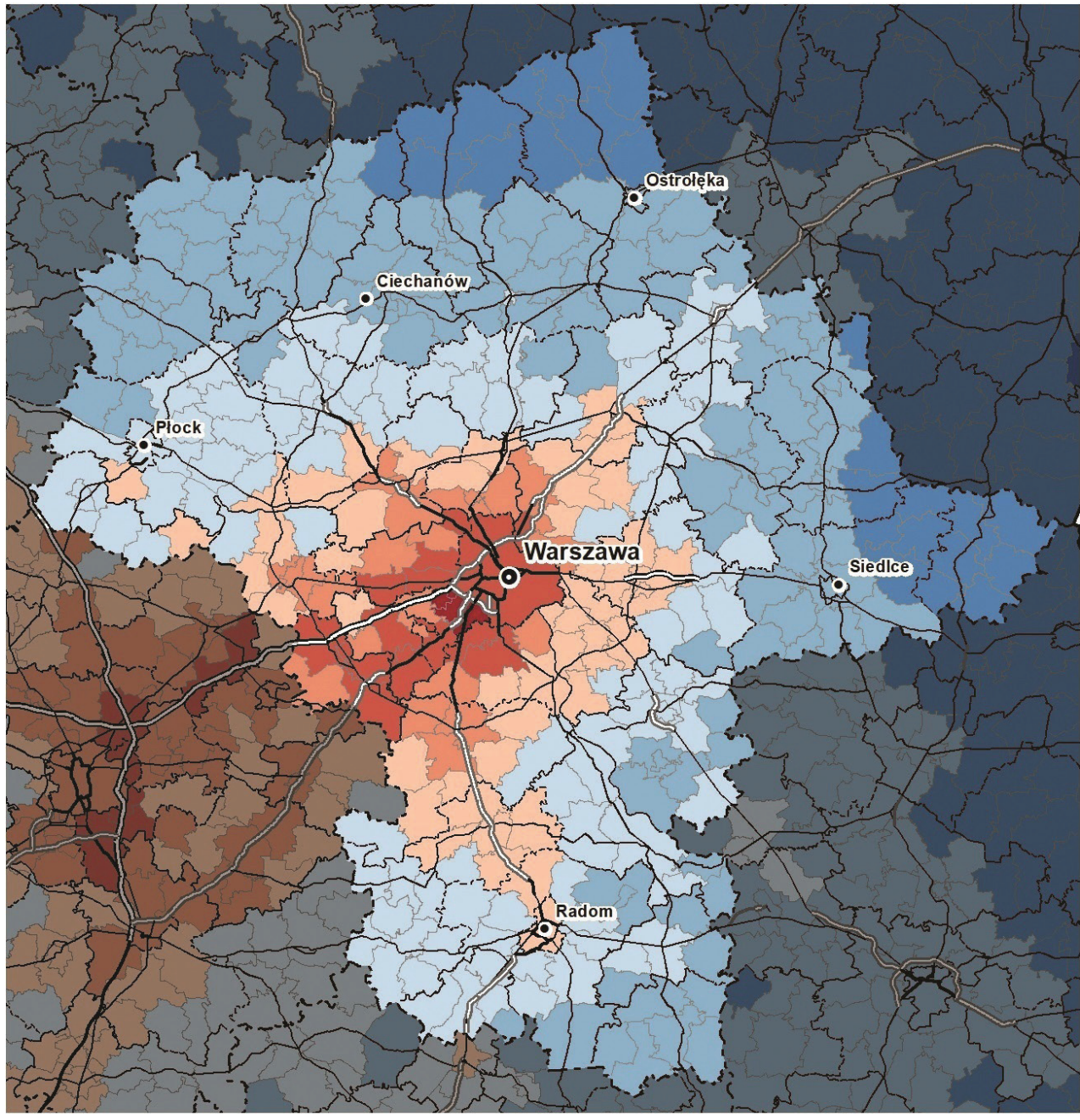

Potential accessibility (2017)

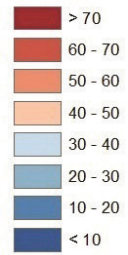

\section{Road category}

Motorway

- Expressway, single carriageway

Expressway, dual carriageway

_ National, dual carriageway

- National

\section{Borders}

- - region

-.--- county

municipality

Fig. 1b. Potential road accessibility of the Mazovia region from the "national level" perspective in 2017

Source: database of IGSO PAS; elaboration: S. Goliszek 


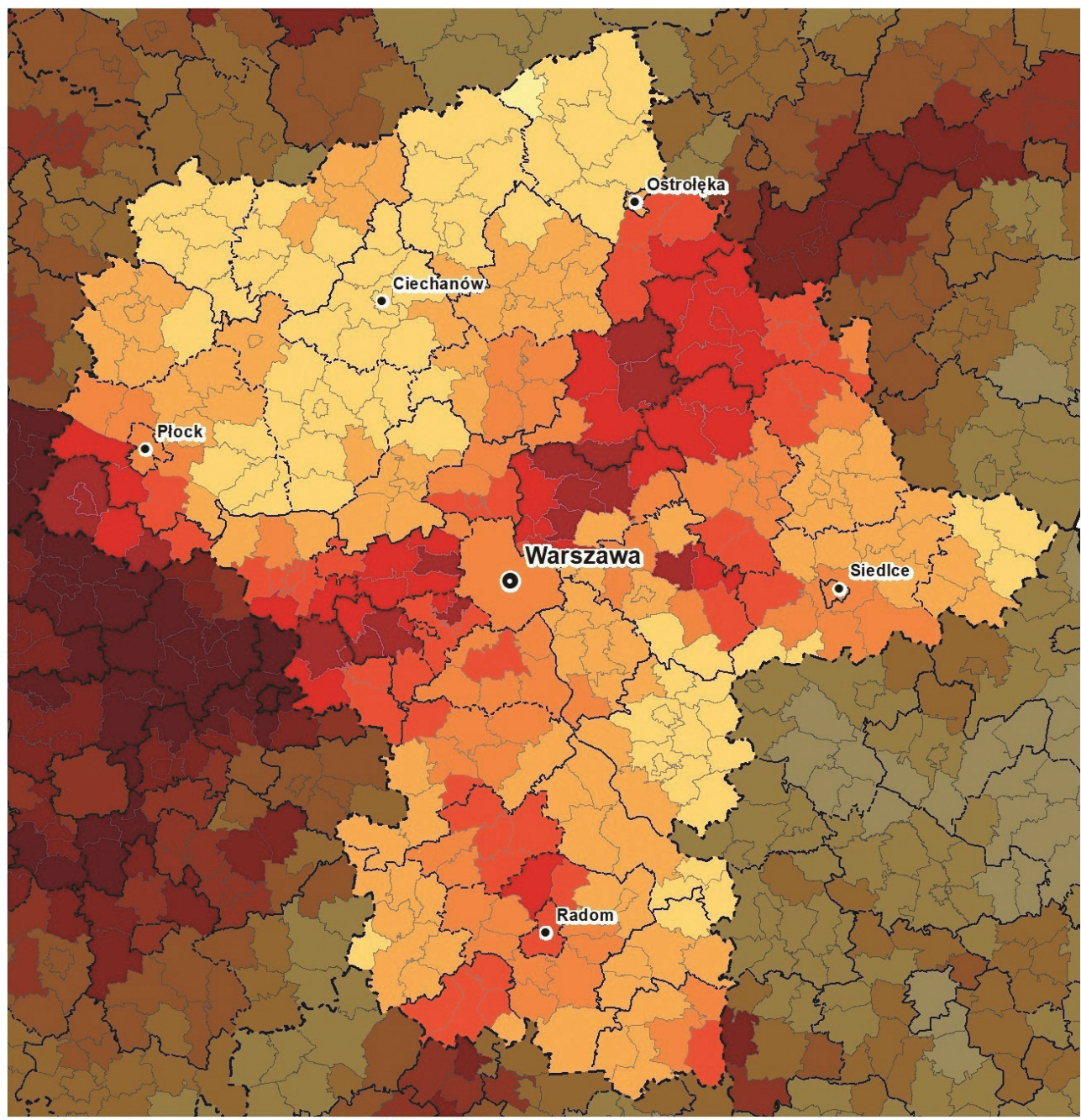

Change of the national potential accessibility (2007-2017; \%)

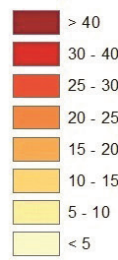

Borders

- - region

$$
\text { ---- county }
$$

municipality

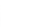

$15 \quad 30$ $60 \mathrm{~km}$

Fig. 2. Changes in the potential road accessibility of the Mazovia region from the "national level" perspective in 2007-2017

Source: database of IGSO PAS; elaboration: S. Goliszek 


\section{Changes in accessibility in Mazovia in the intra-regional perspective}

In monocentric regions like Mazovia, the spatial distribution of the regional potential accessibility is usually concentric. The position of units located farther away from the core (capital) decreases in a natural manner, along with geographical distance. At the same time, this decrease cannot be compensated for by the hypothetical closeness of other larger centres outside of the region, since they are by definition not accounted for in the analysis. Besides, the "masses" of the subregional centres are so small as not to exert any significant influence on the potential accessibility of the adjacent areas. Such a situation occurred in Mazovia in 2007 (Fig. 3a). Deformations to this model scheme appeared along a couple of dual carriageway roads, leading to Warsaw, and in the vicinity of Radom, the biggest of the subregional towns (c. 200000 inhabitants). Other subregional towns were not having a substantial impact on the spatial distribution of the analysed indicator. It can therefore be said that also from the regional perspective they exerted no perceptible influence on the connectivity criterion, corresponding to the polycentricity of the region. Although the year 2017 brought a significant improvement regarding accessibility from the regional perspective, this improvement took place, in general terms, without modifying the previously described concentric pattern. The belts of better accessibility are again well visible along the new motorways and expressways (especially along the A2, S7 and S8, but also along the extensions of the modernized roads). In contrast to the accessibility assessed from the national perspective, in the regional approach the spatial polarization of levels of accessibility was not very pronounced.

The percentage changes in regional accessibility were, in general, smaller than from the national perspective (Fig. 4). At the same time, the spatial pattern of the benefits was largely similar. The differences result, in particular, from the construction and modernization of some of the regional-level routes. An example is provided by the south-western fringes of the region, where the indicator value was influenced by the modernization of the regional road no. 728 from Grójec to Nowe Miasto nad Pilicą.

From the point of view of the subregional centres' role in the polycentric patterns, it is important to assess their position as the poles, surrounded by the islands of zones, featuring higher values of the indicator. The existence of such zones may be evidence of the fact that these towns constitute attractive destinations in terms of functional connections (and not only generate such connections towards the bigger - central - cities). None of the regional and subregional towns in the region of Mazovia has produced such a zone, neither in 2007, nor in 2017 (Fig. 3b). However, the spatial distribution of accessibility change dynamics may indicate the gradual formation of such a zone in the case of Radom. The reason lies in the city's large population, along with the transport projects realized along the S7 expressway. The further direction of changes, though, remains uncertain. Subsequent transport-related projects (including, in particular, a bypass around Radom in the course of the S7) shall contribute to the continued improvement of the city's accessibility. Yet, at the same time, the processes of migration outflow from Radom and the weakening of its demographic position 


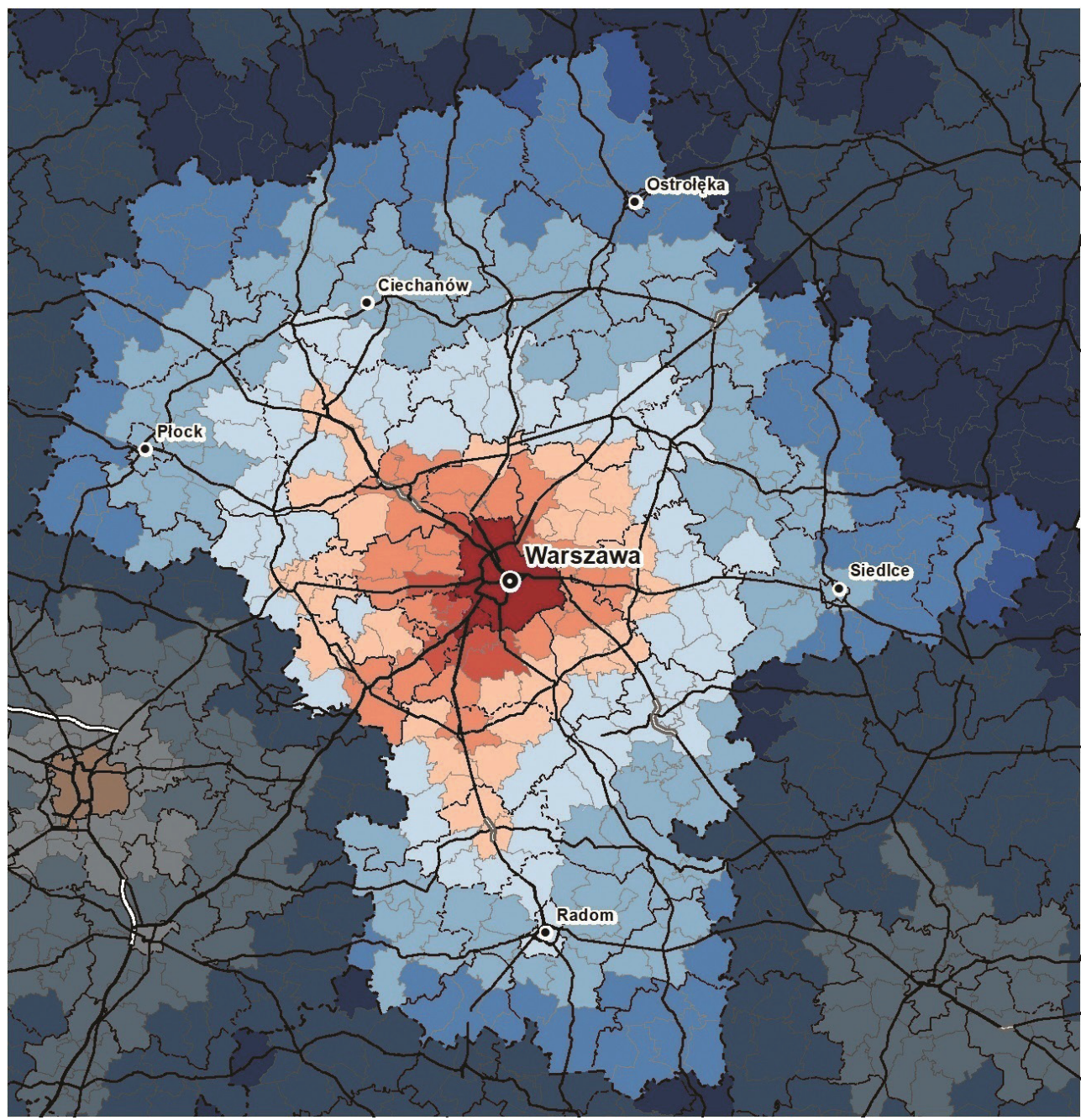

Regional potential accessibility (2007) Road category

Regional $>42$

$36-42$

$30-36$

$24-30$

$18-24$

$12-18$

$6-12$

$<6$

\section{Motorway}

_- Expressway, single carriageway

Expressway, dual carriageway

- National, dual carriageway

National

\section{Borders}

- - region

-- county

municipality

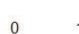

$15 \quad 30$ $60 \mathrm{~km}$

Fig. 3a. Potential road accessibility in the Mazovia region from the regional perspective in 2007 Source: database of IGSO PAS; elaboration: S. Goliszek 


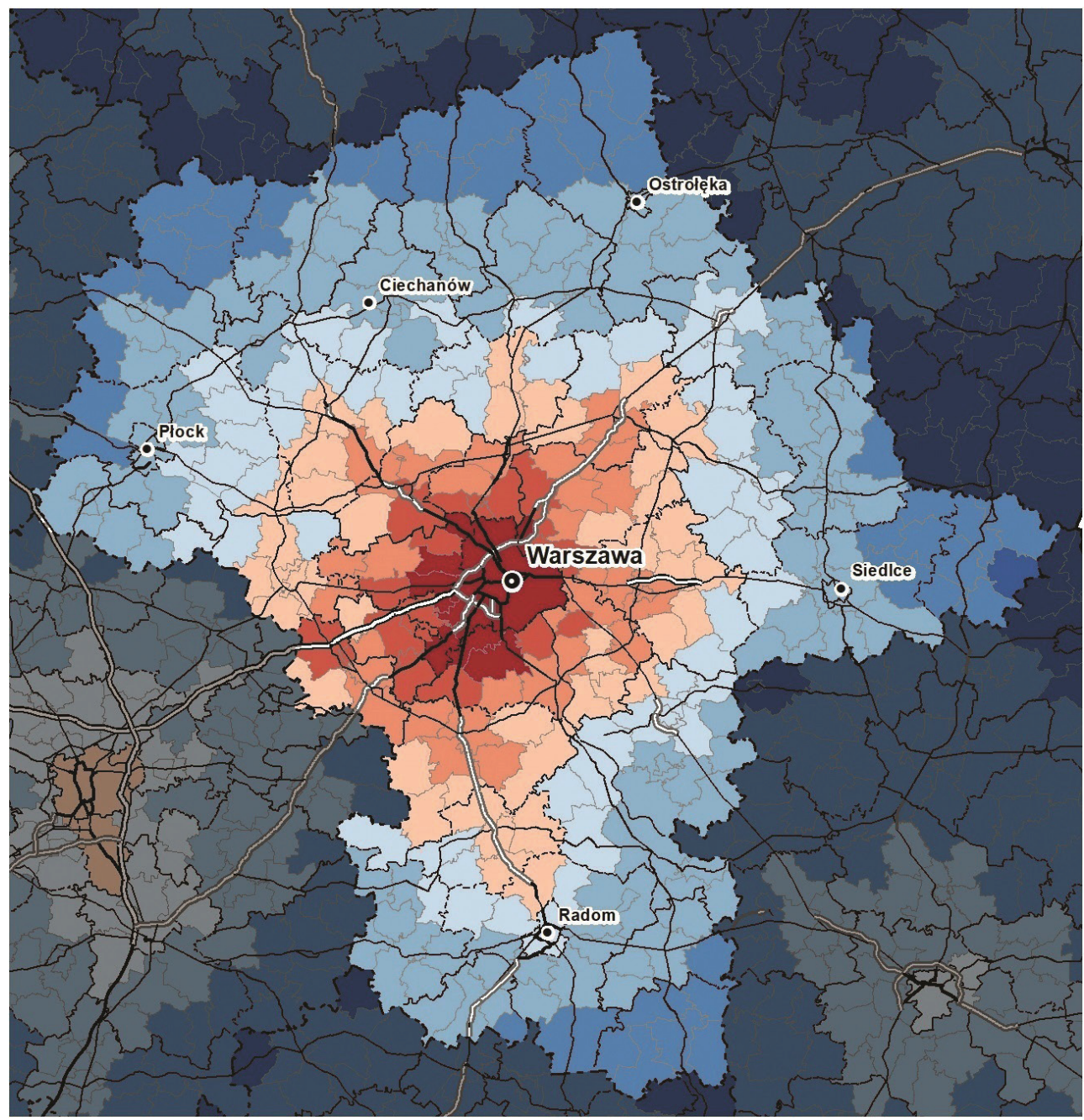

Regional potential accessibility (2017) Road category

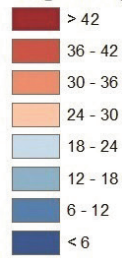

Borders

$$
\begin{aligned}
& =\text { Motorway } \\
& \text { Expressway, single carriageway } \\
& \text { Expressway, dual carriageway } \\
& \text { National, dual carriageway } \\
& \text { National }
\end{aligned}
$$

- - region

---- county

$$
\text { municipality }
$$$$
0
$$

Fig. 3b. Potential road accessibility in the Mazovia region from the regional perspective in 2017 Source: database of IGSO PAS; elaboration: S. Goliszek 


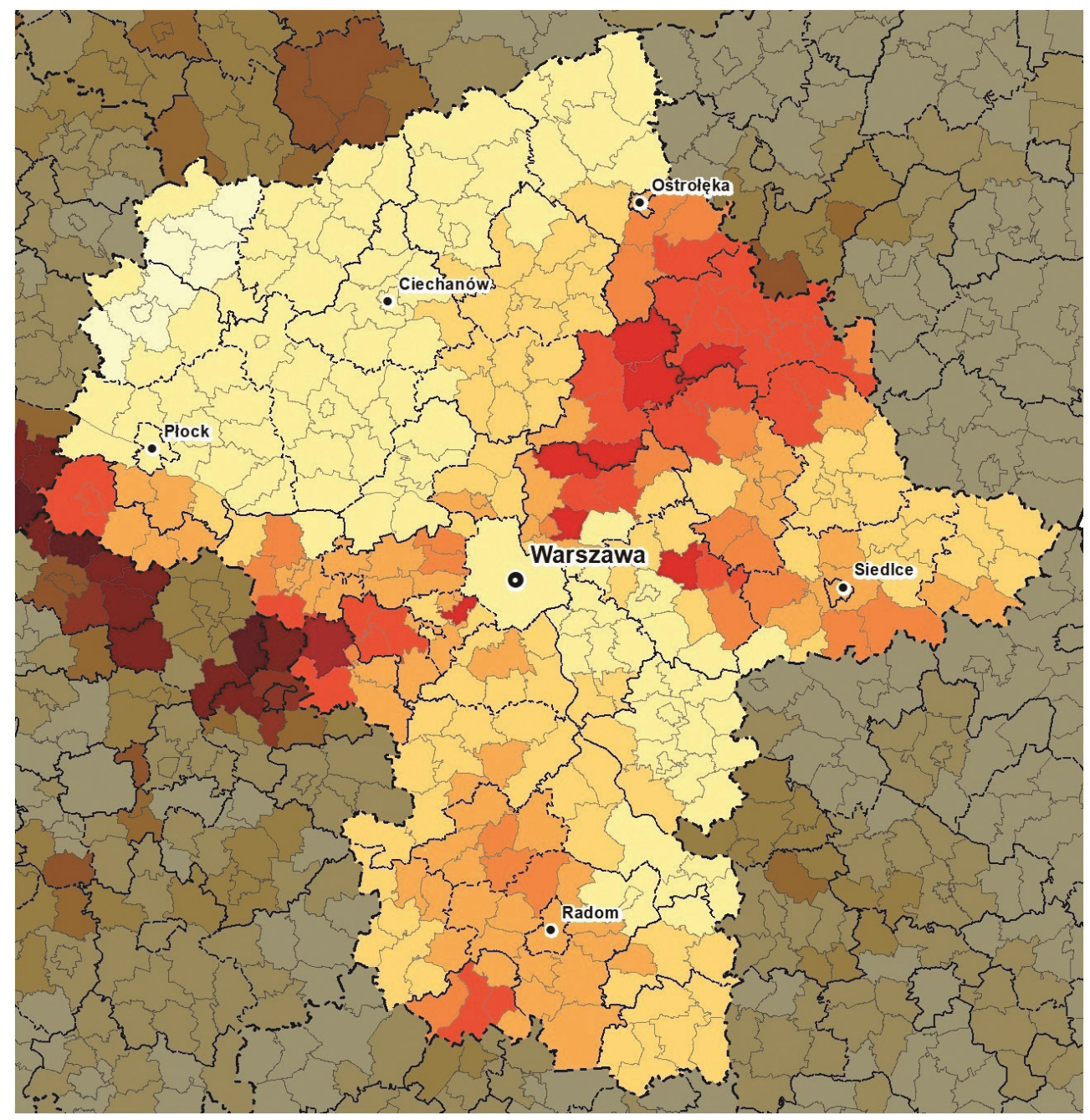

Change of the regional potential accessibility (2007-2017; \%)

Borders

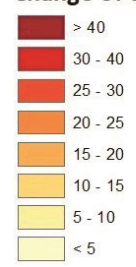

$$
\begin{aligned}
& \text { - - region } \\
& \text {--- county } \\
& \text { _ municipality }
\end{aligned}
$$

$-20$

15

$<5$

Fig. 4. Changes in potential road accessibility in the Mazovia region from the regional perspective in 2007-2017 
shall also continue. The relative balance between these two kinds of processes will decide whether in the future the city shall strengthen or weaken the polycentric structure of the region.

Tendencies which might lead to the appearance of a zone of better accessibility, can also be noticed in the neighbourhood of Siedlce. In the case of Płock, the spatial pattern suggesting such a phenomenon is misleading. The improvement in the regional accessibility of the area to the south of Płock results from the possibility of fast travel to the capital city over the motorway system through the neighbouring region of Lodz.

The analysis of the levels and dynamics of potential road accessibility from the regional perspective also allows for the identification of other centres (county seats), which could become the poles of Mazovia's polycentric development owing to their good transport position (in line with the assumptions of the "basic" scenario, put forward in the Development Trends of Mazovia project). One such towns is certainly Ostrów Mazowiecka (a future node on the Via Baltica route), and potential for playing such a role definitely exists also in the case of Płońsk, Garwolin, Wyszków and Mława.

\section{The position of regional and subregional centres}

For the purpose of assessing the dynamics of polycentric development (the connectivity criterion) an analysis was performed concerning the changes in the accessibility levels of the region and its regional, as well as subregional, centres. A comparison of the results, described earlier, allows for the conclusion that the level of accessibility from the national perspective increased in all the analysed towns to a perceptibly higher extent than from the regional perspective (see Table 1). In relative terms, the increase was the biggest in Radom (improvement by over 26\%), followed by Siedlce, Płock and Warsaw, while Ostrołęka, and particularly Ciechanów benefitted distinctly less. In the case of Siedlce, the fast improvement was partly due to the very low initial indicator value in 2007. An opposite situation can be observed in the case of Warsaw, which started from a high position, but the relative improvement as a consequence of subsequent projects, even in its closest vicinity, is lower. On the other hand, the improvement of Warsaw's accessibility indicator is the highest in absolute terms.

Concerning the regional perspective, the biggest accessibility benefits are visible in the case of Siedlce, Radom and Ostrołęka, while they were decidedly lower for Płock and Ciechanów. Warsaw increased its regional accessibility by nearly $10 \%$, but, again, noted the biggest increment in absolute terms. The effects calculated from the national and regional perspectives were similar in many places due to the monocentric pattern of the settlement network and the geographical location of the region. This was particularly visible in the eastern part of the region where the time of travel to Warsaw was largely the decisive factor for the travel time to other destinations in central and western Poland. This is why the values of increments for such towns as Siedlce and Ostrołęka were very similar in the two 
Table 1. Changes in the potential accessibility in the national and regional perspectives for the biggest Mazovia towns and cities in the years 2007-2017

\begin{tabular}{|l|c|c|c|c|c|c|}
\hline \multirow{2}{*}{ Centres } & \multicolumn{2}{|c|}{ Road accessibility (national perspective) } & \multicolumn{2}{c|}{ Road accessibility (regional perspective) } \\
\cline { 2 - 7 } & 2007 & 2017 & $\begin{array}{c}\text { Changes } \\
(2007=100)\end{array}$ & 2007 & 2017 & $\begin{array}{c}\text { Changes } \\
(2007=100)\end{array}$ \\
\hline Ciechanów & 25.0 & 28.1 & 112.6 & 16.8 & 17.8 & 106.1 \\
\hline Ostrołęka & 18.7 & 22.1 & 117.9 & 11.5 & 13.3 & 116.3 \\
\hline Płock & 29.8 & 36.1 & 121.2 & 15.6 & 16.5 & 105.7 \\
\hline Radom & 33.3 & 42.0 & 126.2 & 18.9 & 22.3 & 118.1 \\
\hline Siedlce & 19.8 & 24.1 & 121.8 & 13.0 & 15.6 & 119.6 \\
\hline WARSAW & 55.9 & 67.7 & 121.1 & 46.4 & 50.8 & 109.4 \\
\hline
\end{tabular}

Source: own elaboration on the basis of the database and model of IGSO PAS

perspectives. Improvement of accessibility in this case was almost entirely dependent upon the construction of roads towards the capital city. The situation was somewhat different in Płock, and to a lesser degree also in Radom and Ciechanów, where the improvement of the transport-related position on the national scale was partly dependent upon the new roads in the direction of other large cities (e.g. towards Lodz and Torun for Płock, towards Kielce and Cracow for Radom, and towards Gdańsk for Ciechanów). However, in the case of Płock and Ciechanów no perceptible shortening of the travel times to Warsaw was observed. Hence, the level of regional accessibility improved only slightly. The results obtained confirm the crucial role of the segments of motorways and expressways in the vicinity of the biggest metropolises. They influence the accessibility transport-wise at various geographical scales, and their shortage significantly limits the chances of some towns to play a role in equilibrating the polycentric development within larger regions.

A comparison of just the travel times in road transport between the regional and subregional centres of the region (Table 2) indicates the monocentric character of the investment projects undertaken. The biggest benefits (shortening of travel times by more than $10 \%$ ) were observed first of all for the connections with Warsaw (from Radom, Siedlce and Ostrołęka) and between those pairs of towns for which the shortest route leads through Warsaw (e.g. Radom and Ostrołęka). Changes to the remaining connections were insignificant.

Travel times to Warsaw from Płock and Ciechanów have practically remained unchanged. It is characteristic that also no improvement in the mutual time-wise accessibility took place between the closely situated subregional towns (e.g. Ciechanów and Ostrołęka). This implies a lack of beltway-type projects (except for the express ring of Warsaw, which, however, has an intra-metropolitan character). 
Table 2. Travel times (in hours) between the biggest towns of the Mazovia region and changes in 2007-2017

\begin{tabular}{|c|c|c|c|c|c|c|}
\hline \multicolumn{7}{|c|}{2007} \\
\hline Centres & Ciechanów & Ostrołęka & Płock & Radom & Siedlce & WARSAW \\
\hline Ciechanów & & 1.21 & 1.12 & 2.69 & 2.21 & 1.35 \\
\hline Ostrołęka & 1.21 & & 2.33 & 3.19 & 1.86 & 1.86 \\
\hline Płock & 1.12 & 2.33 & & 2.42 & 2.94 & 1.49 \\
\hline Radom & 2.69 & 3.19 & 2.42 & & 2.46 & 1.34 \\
\hline Siedlce & 2.21 & 1.86 & 2.94 & 2.46 & & 1.54 \\
\hline WARSAW & 1.35 & 1.86 & 1.49 & 1.34 & 1.54 & \\
\hline \multicolumn{7}{|c|}{2017} \\
\hline Centres & Ciechanów & Ostrołęka & Płock & Radom & Siedlce & WARSAW \\
\hline Ciechanów & & 1.21 & 1.11 & 2.44 & 2.20 & 1.34 \\
\hline Ostrołęka & 1.21 & & 2.32 & 2.77 & 1.84 & 1.67 \\
\hline Płock & 1.11 & 2.32 & & 2.26 & 2.75 & 1.49 \\
\hline Radom & 2.44 & 2.77 & 2.26 & & 2.22 & 1.19 \\
\hline Siedlce & 2.20 & 1.84 & 2.75 & 2.22 & & 1.36 \\
\hline WARSAW & 1.34 & 1.67 & 1.49 & 1.19 & 1.36 & \\
\hline \multicolumn{7}{|c|}{ 2007-2017 change (\%) } \\
\hline Centres & Ciechanów & Ostrołęka & Płock & Radom & Siedlce & WARSAW \\
\hline Ciechanów & & 100.0 & 99.4 & 90.8 & 99.4 & 99.5 \\
\hline Ostrołęka & 100.0 & & 99.7 & 86.9 & 99.0 & 89.5 \\
\hline Płock & 99.4 & 99.7 & & 93.4 & 93.7 & 99.7 \\
\hline Radom & 90.8 & 86.9 & 93.4 & & 89.9 & 88.2 \\
\hline Siedlce & 99.4 & 99.0 & 93.7 & 89.9 & & 88.3 \\
\hline WARSAW & 99.5 & 89.5 & 99.7 & 88.2 & 88.3 & \\
\hline
\end{tabular}

Source: own elaboration on the basis of the database and model of IGSO PAS 


\section{Conclusions}

In 2007-2017 road accessibility in the entire region of Mazovia improved both from the national and regional perspectives. This was mainly due to large national-level projects (motorways and expressways) and, to a lesser degree, some modernizations of regional routes. Consequently, improvement was more pronounced from the national perspective. The spatial differentiation of accessibility changed its character. It ceased to result directly from the geographical distribution of towns and from the historical division, associated with the course of Vistula. It became the effect of advancement in realization of road projects.

The region has been and remains monocentric. The implemented projects allowed for the strengthening of some of the regional (Radom) and subregional (Siedlce, Ostrołęka) centres, providing the capacity for increasing the degree of polycentricity. The true effect of these undertakings, however, has to be assessed in the demographic context. The development of infrastructure may to some extent compensate for the demographic losses (e.g. through the spatial extension of the local labour markets). It cannot balance, however, the fast depopulation processes. There are some parts of the region, where accessibility has not improved (especially in the north, including the town of Ciechanów), or improved only from the national perspective (connections with other big cities of Poland, as in the case of the northwestern fringe of the region, including the town of Płock). It can therefore be concluded that the road projects exerted an altogether positive influence on the polycentricity of the region. Until now, though, this influence has been spatially selective. It should rather be regarded as the formation of an opportunity for a more balanced settlement pattern. Whether this opportunity will be made use of depends upon the demographic situation and the triggering of other endogenous development potentials in the regional and subregional towns.

The implemented infrastructural policies have, however, a long-term character. The condition for the ultimate strengthening of the polycentric pattern of the urban system is to consistently continue these policies. Along with the acceleration of investment projects which took place after the accession of Poland to the European Union, there was an increase in the territorial differentiation of the spatial accessibility indicator values. This study demonstrates that this happened not only at the national level, but also at the intraregional one. Mazovia became more polarized in terms of road accessibility. This is a natural phenomenon. The smaller differences in the initial year of study, 2007, were the effect of the generally bad state of infrastructure. The modernisation of selected routes always leads to increased polarization. That is why, as has been already mentioned, the projects implemented in Mazovia strengthened some of the centres of the hypothetical polycentric setting (Radom, Siedlce), while not strengthening the others. If the road projects in the region were stopped (e.g. due to lack of access to European Union funds in the financial perspective after 2020), then Mazovia would remain with the transport infrastructure ensuring generally better accessibility than 20 years earlier, but, at the same time, amounting to a much higher polarization of this accessibility than 20 years earlier. This might entail a strengthening of the polycentric setting to the south and west of Warsaw, but its weakening - and therefore peripheralisation - in other parts of the region. 
Referring to the alternative scenarios of the polycentric development of Mazovia, formulated at the beginning of the article, it can be stated that the investment projects to date are to a certain extent conducive to the realization of the "basic" scenario. The position of Radom improved significantly in terms of the connectivity criterion, both from the national and regional perspective. The second regional centre, Płock, also gained distinctly, mainly from the national perspective. Significant increments in accessibility in the eastern part of the region often result from the low initial values of the indicators. They can turn out to be insufficient for maintaining the polycentric structure based on the subregional centres. Simultaneously, the realized projects distinctly strengthened some other county towns, which could become the new poles of equilibrating development (e.g. Ostrów Mazowiecka).

\section{References}

Bański J., Czapiewski K., 2015, A vision of the polycentric development of the Mazovia region in Poland, Geographical Journal, 67, 4, pp. 301-321.

Copus A.K., 2001, From core-periphery to polycentric development: concepts of spatial and aspatial peripherality, European Planning Studies, 9, 4, pp. 539-552.

ESDP, 1999, European Spatial Development Perspective. Towards Balanced and Sustainable Development of the Territory of the European Union, Agreed at the Informal Council of Ministers responsible for Spatial Planning in Potsdam, May 1999, Published by the European Commission, Office for Official Publications of the European Communities, Luxembourg.

ESPON, 2004, Potentials for Polycentric Development in Europe, ESPON Project 1.1.1., Luxembourg.

ESPON 1.1.3. Final Report, 2006, www.espon.eu

ESPON 1.2.1. Final Report, 2004, www.espon.eu

ESPON FOCI Final Report, 2010, www.espon.eu

ESPON SeGI Interim Report, 2012, www.espon.eu

ESPON TRACC Interim Report, 2012, www.espon.eu

Geurs K.T., Ritsema van Eck J.R., 2001, Accessibility measures: review and applications. Evaluation of accessibility impacts of land-use transportation scenarios, and related social and economic impast, RIVM report 408505 006, National Institute of Public Health and the Environment, Bilthoven.

Geurs K.T., van Wee B., 2004, Accessibility evaluation of land-use and transport strategies: review and research directions, Journal of Transport Geography, 12, 2, pp. 127-140. 
Hansen W.G., 1959, How accessibility shapes land-use, Journal of the American Institute of Plannners, 25, 2, pp. 73-76.

Bohme K., Doucet P., Komornicki T., Zaucha J., Świątek D., 2011, How to strengthen the territorial dimension of Europe 2020 and the EU Cohesion Policy, Report based on the Territorial Agenda 2020, Ministerstwo Rozwoju Regionalnego, Warszawa.

Komornicki T., Rosik P., 2012, Przesłanki i kierunki rozwoju infrastruktury transportowej na Mazowszu, Mazowsze. Studia Regionalne, 11, pp. 11-35.

Komornicki T., Rosik P., Stępniak M., Śleszyński P., Goliszek P., Pomianowski W., Kowalczyk K., 2018, Evaluation and monitoring of accessibility changes in Poland using the MAI indicator, IGSO PAS, MIED, Warsaw.

Komornicki T., Śleszyński P., Rosik P., Pomianowski W., 2010, Dostępność przestrzenna jako przesłanka kształtowania polskiej polityki transportowej, Biuletyn, 241, KPZK PAN, Warszawa.

Komornicki T., Stępniak M., 2015, New investment projects in the road corridors and the improvement of the potential accessibility in Poland, EUROPA XXI, 28, IGiPZ PAN, Warszawa, pp. 30-51.

Komornicki T., Wiśniewski R., Stępniak M., Siłka P., Rosik P., 2013, Rynekpracy w województwie mazowieckim, Mazowsze. Studia Regionalne, 12, pp. 11-38.

Komornicki T., Wiśniewski R., Stępniak M., Siłka P., Rosik P., 2013, Rynek pracy województwa mazowieckiego - analiza przestrzenna, Trendy Rozwojowe Mazowsza, 12, MBPR, Warszawa.

Komornicki T., Bański J., Śleszyński P., Rosik P., Czapiewski K., Korcelli P., Świątek D., Degórska B., Siłka P., Wiśniewski R., Stępniak M., Mazur M., 2012, Zagospodarowanie infrastrukturalne i kapitał fizyczny oraz policentryczność rozwoju Mazowsza, Trendy Rozwojowe Mazowsza, 4, MBPR, Warszawa.

Kunzmann K.R., Wegener M., 1991, The pattern of urbanisation in western Europe 1960-1990, Berichte aus dem Institut für Raumplanung, 28, Institut für Raumplanung, Universität Dortmund, Dortmund.

Meijers E.J., Waterhout B., Zonneveld W.A.M., 2007, Closing the gap: territorial cohesion through polycentric development, European Journal of Spatial Development, 24, http://www.nordregio. se/EJSD/refereed24.pdf

Ministry of Regional Development, 2011, National Spatial Development Concept, Ministry of Regional Development, Warsaw. 
Plan zagospodarowania przestrzennego województwa mazowieckiego, 2014, Urząd Marszałkowski Województwa Mazowieckiego, Warszawa.

Rosik P., Stępniak M., Komornicki T., 2015, The decade of the big push to roads in Poland: impact on improvement in accessibility and territorial cohesion from a policy perspective, Transport Policy, 37, pp. 134-14.

Rosik P., 2012, Dostępność ladowa przestrzeni Polski w wymiarze europejskim, Prace Geograficzne, 233, IGiPZ PAN, Warszawa.

Śleszyński P., Bierzyński A., Cerić D., Ciechański A., Degórska B., Degórski M., Komornicki T., Korcelli-Olejniczak E., Piotrowski F., Stępniak M., Węcławowicz G., Wiśniewski R., 2017, Analiza sytuacji rozwojowej miast, w tym charakterystyka miast tracacych funkcje społecznogospodarcze, Raport dla Ministerstwa Rozwoju.

Spiekermann K., Schürmann C., 2007, Update of selected potential accessibility indicators. Final report, Spiekermann \& Wegener, Urban and Regional Research (S\&W), RRG Spatial Planning and Geoinformation.

Spiekermann K., Wegener M., Květoň V., Marada M., Schürmann C., Biosca O., Ulied Segui A., Antikainen H., Kotavaara O., Rusanen J., Bielańska D., Fiorello D., Komornicki T., Rosik P., Stępniak M., 2013, TRACC Transport Accessibility at Regional/Local Scale and Patterns in Europe, Draft Final Report, ESPON Applied Research.

Territorial Agenda, 2007, Territorial Agenda of the European Union - Towards a More Competitive and Sustainable Europe of Diverse Regions - Agreed at the Informal Ministerial Meeting on Urban Development and Territorial Cohesion on 24/25 $5^{\text {th }}$ May, Leipzig, Germany.

Territorial Agenda, 2011, Territorial Agenda of the European Union 2020 - Towards an Inclusive, Smart and Sustainable Europe of Diverse Regions - Agreed at the Informal Ministerial Meeting of Ministers Responsible for Spatial Planning and Territorial Development on $19^{\text {th }}$ May, Gödöllő, Hungary.

Zaucha J., Komornicki T., Böhme K., Świątek D., Żuber P., 2014, Territorial keys for bringing closer the territorial agenda of the EU and Europe 2020, European Planning Studies, 22, 2, pp. 246-267.

Zaucha J., Szlachta J., 2017, Territorial Cohesion: Origin, content and operationalization [in:] J. Bradley, J. Zaucha (eds) Territorial Cohesion: A missing link between economic growth and welfare. Lessons from the Baltic Tiger, University of Gdańsk and Institute for Development, Gdańsk, pp. 23-47. 


\section{IMPROVEMENT IN ROAD ACCESSIBILITY VS. THE POLYCENTRICITY OF THE MAZOVIAN... \\ Tomasz Komornicki}

\section{Poprawa dostępności drogowej a policentryczny układ sieci osadniczej Mazowsza}

\section{STRESZCZENIE}

Celem niniejszego artykułu jest ocena, na ile zrealizowane inwestycje drogowe przyczyniły się do wzmocnienia układu policentrycznego województwa mazowieckiego. Przeprowadzone badanie może także umożliwić szerszą refleksję nad skutecznością polityki transportowej w kontekście najważniejszych celów polityki przestrzennej i spójności terytorialnej UE. Zakres przestrzenny opracowania obejmuje województwo mazowieckie, ale wykonane analizy odnoszą się także do całego kraju. Przeprowadzona analiza ma charakter dynamiczny i obejmuje okres $2007-2017$. Stwierdzono, że w latach 2007-2017 na terenie całego województwa mazowieckiego doszło do poprawy dostępności zarówno w ujęciu krajowym, jak i regionalnym. Przyczyną były głównie duże inwestycje krajowe, a w mniejszym stopniu także niektóre modernizacje tras wojewódzkich. Układ zróżnicowań przestrzennych dostępności zmienił swój charakter. Przestał wynikać bezpośrednio z rozkładu geograficznego miast oraz z historycznego podziału nawiązującego do linii Wisły. Stał się rezultatem stanu zaawansowania procesu inwestycyjnego. Zrealizowane inwestycje pozwoliły na wzmocnienie niektórych ośrodków regionalnych (Radom) i subregionalnych (Siedlce, Ostrołęka), tworząc możliwości zwiększenia poziomu policentryczności. Rzeczywisty efekt tych działań musi być jednak oceniany w kontekście demograficznym. W niektórych częściach województwa poprawa dostępności nie nastąpiła (szczególnie na północy; w tym w Ciechanowie) lub dokonała się głównie na poziomie krajowym (relacje z innymi dużymi miastami Polski, jak w przypadku krańców północno-zachodnich, w tym Płocka). Można tym samym stwierdzić, że inwestycje drogowe miały pozytywny wpływ na policentryczność regionu. Jak dotąd jest to jednak wpływ selektywny przestrzennie. Trzeba go traktować raczej jako szansę na bardziej zrównoważony układ osadniczy. Wykorzystanie tej szansy zależy od sytuacji demograficznej oraz od pobudzenia innych endogenicznych potencjałów rozwojowych w miastach regionalnych i subregionalnych.

Słowa kluczowe: dostępność, województwo mazowieckie, Mazowsze, policentryczność, drogi

Professor Tomasz Komornicki, born 1963, a graduate of Warsaw University (1988), PhD in Polish Academy of Sciences (1998), head of the Department of Spatial Organization in the Institute of Geography and Spatial Organization Polish Academy of Sciences (PAS), professor at the Faculty of Earth Sciences and Spatial Management, Maria Curie-Sklodowska University in Lublin; member of the executive body of the Committee for Spatial Economy and Regional Planning, PAS, head and participant of many Polish and international research projects, including HORIZON, ESPON and INTERREG projects); member of the Consulting Board for preparation of the new Spatial Development Concept of Poland up to 2030 (in the Ministry of Regional Development); member of the international scientific team preparing the Territorial Agenda of the European Union 2020. Author of more than 400 scientific publications. His main areas of interest are socio-economic geography, transport geography and spatial planning.

Prof. dr hab. Tomasz Komornicki jest absolwentem Uniwersytetu Warszawskiego. Obecnie pełni funkcję Kierownika Zakładu Przestrzennego Zagospodarowania w Instytucie Geografii i Przestrzennego Zagospodarowania Polskiej Akademii Nauk, w latach 2010-2017 z-ca Dyrektora tegoż Instytutu. Zajmuje się geografią społeczno-ekonomiczna, polityką transportową oraz planowaniem przestrzennym. Jest członkiem prezydium Komitetu Przestrzennego Zagospodarowania Kraju PAN. Był lub jest kierownikiem ponad 40 krajowych i międzynarodowych projektów badawczych, w tym projektów ESPON (European Spatial Planning Observation Network). Jest autorem ponad 400 publikacji naukowych, z czego około 60 zagranicznych. W latach 2010-2011 był członkiem międzynarodowego zespołu przygotowującego Agendę Terytorialnq Unii Europejskiej 2020. W okresie 2006-2011 był członkiem zespołu ekspertów opracowujących Koncepcję Przestrzennego Zagospodarowania Kraju 2030. W latach 2014-2015 kierował zespołem, który opracował Wskaźnik Międzygałęziowej Dostępności Transportowej (WMDTII) dla Ministerstwa Inwestycji i Rozwoju. 